\title{
Bacteria from solid tumours
}

\section{BROOK*}

\section{Naval Hospital, Bethesda, MD, USA}

\begin{abstract}
Summary. Bacteria were grown from $63(69 \%)$ of 91 specimens from necrotic tumours in 63 patients. Of the tumours, 14 were abdominal, 5 pelvic, 23 of the head and neck, 4 of the lungs, 4 mediastinal, 2 lymphatic, 3 of the breast, and 8 were miscellaneous. Aerobic or facultatively anaerobic bacteria only were present in $12(19 \%)$ specimens, anaerobes only in $10(16 \%)$, and mixed aerobic and anaerobic bacteria in $41(65 \%)$. A total of 83 anaerobic and 47 aerobic and facultatively anaerobic bacteria were isolated. The predominant anaerobic bacteria were Bacteroides spp. (36 isolates), and anaerobic cocci (21) and Propionibacterium acnes (22). The aerobic and facultatively anaerobic bacteria most frequently isolated were Staphylococcus aureus, $\alpha$-haemolytic streptococci, Escherichia coli (seven isolates each), S. epidermidis, Klebsiella pneumoniae and Pseudomonas aeruginosa (five isolates each). These data demonstrate that infection of tumours is usually polymicrobial.
\end{abstract}

\section{Introduction}

Infection is one of the major obstacles to the successful management of patients with malignant tumours (Bodey, 1986), and is often suspected in cancer patients who develop fever, especially when associated with neutropenia. Although most infections in febrile neutropenic patients are systemic, in a large number no obvious source of infection is found. Infection in the tumour mass may account for some of these febrile episodes. Although infection of necrotic tumours has been recognised, the microbiology of such infections has not been studied adequately.

This study was designed to identify the bacteria present in infected solid tumours and to correlate them with tumour sites.

\section{Patients and methods}

\section{Patients}

Between 1976 and 1984, 91 specimens from tumours thought to be infected were obtained from 63 in-patients (39 males) aged 13-74 (mean 52) years at Walter Reed Army Medical Center, Washington, DC, and the Navy Hospital, Bethesda, MD.

The sites of the tumours from which specimens were obtained were: abdomen 14 (colon and rectum 6, liver 4,

Received 20 Mar. 1989; accepted 10 Jan. 1990.

* Correspondence should be sent to Dr I. Brook, Armed Forces Radiobiology Research Institute, Bethesda, MD 20814-5145, USA. peritoneum 2, small intestine 2); ovary 4; uterus 1 ; head and neck 23 (lymph nodes 7, thyroid 4, parotid and salivary glands 4 , larynx 3 , paranasal sinuses 3 , intracranial 2); lungs 4; mediastinum 4; lymphatic (axilla and groin) 2; breast 3 ; and miscellaneous 8 (skin 2, muscle in extremities 2, heart 2, kidney 1 , and adrenal 1 ).

Antimicrobial therapy (penicillins in 15 patients, cephalosporins 1 , aminoglycosides 7 , and clindamycin 6 ) had been given to 28 of these patients before sample collection.

Forty-four patients had clinical signs of infection, including fever (temperature $>38.5^{\circ} \mathrm{C}$ ) in 31 and leucocytosis $\left(>12000 \mathrm{wbc} / \mathrm{mm}^{3}\right)$ in 24 .

\section{Isolation and identification of bacteria}

Specimens were taken during surgery only from solid tumours suspected of being infected, by aspirating pus or by swabbing infected areas, taking care to avoid contact with adjacent mucous membranes. The aspirated specimens were transported to the laboratory in the syringe used to collect them, capping the needle with a rubber stopper. Swabs were transported in anaerobic transport medium (Port-A-Cul, BBL Microbiological Systems, Becton Dickinson, Cockeysville, MD). The time between specimen collection and culture never exceeded $2 \mathrm{~h}$.

Aerobic bacteria were sought by culture on sheep blood agar, heated blood agar, and MacConkey's agar plates, incubated at $37^{\circ} \mathrm{C}$, aerobically (MacConkey's agar) or in $\mathrm{CO}_{2} 5 \%$; the plates were examined after 24 and $48 \mathrm{~h}$. To isolate anaerobic bacteria, the specimens were plated at the bench on to reduced brucella blood agar enriched with vitamin $\mathrm{K}_{1} 10 \mathrm{mg} / \mathrm{mL}$, a blood-agar plate containing kanamycin $100 \mathrm{mg} / \mathrm{L}$ and vancomycin $7.5 \mathrm{mg} / \mathrm{L}$, and a blood-agar plate containing phenylethyl alcohol $42.5 \mathrm{~g} / \mathrm{L}$ 
and were inoculated into enriched thioglycollate broth containing haemin $5 \mathrm{mg} / \mathrm{L}$ and vitamin $\mathrm{K}_{1} 1 \mathrm{mg} / \mathrm{L}$ (Sutter et al., 1985). The plates were incubated in GasPak jars (BBL, Cockeysville, MD) and examined after 48 and $96 \mathrm{~h}$. The thioglycollate broth was incubated for 14 days. Aerobic and anaerobic bacteria were identified by conventional techniques (Lennette et al., 1985; Sutter et al., 1985).

\section{Results}

Bacteria grew from $63(69 \%)$ of the 91 specimens examined. Either aerobic or facultatively anaerobic bacteria only were present in $12(19 \%)$ of the 63 specimens, anaerobic bacteria only in $10(16 \%)$, and mixed aerobic and anaerobic bacteria in 41 $(65 \%)$ (table I). The average number of isolates from infected tumours was $2 \cdot 1$ (range 1-5). The highest average number of isolates was from pelvic, lymphatic and breast tumours (2.6-3/specimen).

A total of 83 isolates of anaerobic bacteria (average 1.3 isolates/specimen) and 47 of aerobic and facultatively anaerobic bacteria (average 0.7 isolates/specimen) were obtained (table II). The predominant anaerobic bacteria were Bacteroides spp. (36 isolates, including 17 from the $B$. fragilis group), anaerobic gram-positive cocci (20 isolates), and Propionibacterium acnes (22 isolates, 12 from tumours of the head and neck). Seven of the $22 P$. acnes isolates grew in thioglycollate broth only.

The commonest aerobic and facultatively anaerobic bacteria isolated were Staphylococcus aureus, $\alpha$-haemolytic streptococci and Escherichia coli (seven isolates each), and S. epidermidis, Klebsiella pneumoniae, and Pseudomonas aeruginosa (five isolates each).

Using Student's $t$ test, statistically significant differences were not found in the number or diversity of organisms isolated from 16 different anatomical sites, nor was there any correlation between the bacterial species isolated and the site of the tumours, except for increased isolation of organisms of the $\boldsymbol{B}$. fragilis group from abdominal tumours ( 8 of 17 isolates), and of $P$. acnes from tumours of the head and neck (all of 12 isolates). However, significantly fewer organisms were isolated from patients who had received antimicrobials ( 38 isolates from 28 patients, 1.4 isolates/specimen) than in patients who had not received antimicrobials (92 isolates from 35 patients, 2.6 isolates/ specimen). None of the $17 \mathrm{~B}$. fragilis group isolates were from patients who had received clindamycin.

\section{Discussion}

The results of this study demonstrate that anaerobic bacteria are often present in infected solid tumours and support the findings of Rotimi and Durosinmi-Etti (1984), who isolated anaerobes predominantly from infected malignant ulcers in 70 patients - of a total of 282 isolates, $179(63 \%)$ were anaerobes. Further support for the importance of anaerobic bacteria in infections of solid tumours comes from the effect of anti-anaerobe antimicrobial agents. In the present study, organisms of the $B$. fragilis group were not isolated from infected tumours in patients who had been treated with clindamycin. Similar findings have been described by Sinkovics and Smith (1970), Klastersky et al. (1977, 1979), Ashby et al. (1978), Lagast and Klastersky (1982), and Lagast et al. (1982), although the detailed microbiology of infected tumours was not described in these studies.

The anaerobes isolated from infected tumours probably originate from mucous membranes adjoining the tumour site, so explaining the predominance of organisms of the $B$. fragilis group in

Table I. Characteristics of 63 infected solid tumours

\begin{tabular}{|c|c|c|c|c|c|c|c|c|c|}
\hline \multirow[b]{2}{*}{$\begin{array}{l}\text { Tumour } \\
\text { sites }\end{array}$} & \multirow[b]{2}{*}{$\begin{array}{l}\text { Number of } \\
\text { specimens }\end{array}$} & \multirow{2}{*}{$\begin{array}{c}\text { Number of } \\
\text { anaerobic } \\
\text { isolates }\end{array}$} & \multirow{2}{*}{$\begin{array}{l}\text { Number of } \\
\text { aerobic } \\
\text { isolates }\end{array}$} & \multirow{2}{*}{$\begin{array}{l}\text { Anaerobes/ } \\
\text { sample }\end{array}$} & \multirow[b]{2}{*}{$\begin{array}{l}\text { Aerobes/ } \\
\text { sample }\end{array}$} & \multirow[b]{2}{*}{$\begin{array}{l}\text { Isolates/ } \\
\text { sample }\end{array}$} & \multicolumn{3}{|c|}{ Number $(\%)$ of samples with } \\
\hline & & & & & & & $\begin{array}{c}\text { Anaerobes } \\
\text { only }\end{array}$ & $\begin{array}{c}\text { Aerobes } \\
\text { only }\end{array}$ & $\begin{array}{c}\text { Anaerobes } \\
\text { + aerobes }\end{array}$ \\
\hline Abdomen & 14 & 17 & 13 & $1 \cdot 2$ & 0.9 & $2 \cdot 1$ & $3(21)$ & $1(7)$ & $10(71)$ \\
\hline Pelvis & 5 & 9 & 4 & 1.8 & 0.8 & $2 \cdot 6$ & $1(20)$ & 0 & $4(80)$ \\
\hline Head and neck & 23 & 26 & 15 & $1 \cdot 1$ & 0.7 & 1.8 & $3(13)$ & $7(30)$ & $13(57)$ \\
\hline Lung & 4 & 4 & 4 & $1 \cdot 0$ & $1 \cdot 0$ & $2 \cdot 0$ & $1(25)$ & $1(25)$ & $2(50)$ \\
\hline Mediastinum & 4 & 4 & 3 & 1.0 & 0.7 & 1.7 & 0 & $1(25)$ & $3(75)$ \\
\hline Lymphatic & 2 & 4 & 2 & $2 \cdot 0$ & $1 \cdot 0$ & $3 \cdot 0$ & 0 & 0 & $2(100)$ \\
\hline Breast & 3 & 7 & 2 & $2 \cdot 3$ & 0.7 & 3.0 & $1(33)$ & 0 & $2(67)$ \\
\hline Miscellaneous & 8 & 12 & 4 & 1.5 & 0.5 & $2 \cdot 0$ & $1(12)$ & $2(25)$ & $5(63)$ \\
\hline Total & 63 & 83 & 47 & $1 \cdot 3$ & 0.7 & $2 \cdot 1$ & $10(16)$ & $12(19)$ & $41(65)$ \\
\hline
\end{tabular}


Table II. Frequency of isolation of aerobic and anaerobic bacteria from 63 specimens from infected solid tumours

\begin{tabular}{|c|c|c|c|c|c|c|c|c|c|}
\hline \multirow[b]{2}{*}{$\begin{array}{l}\text { Species of } \\
\text { bacteria }\end{array}$} & \multicolumn{9}{|c|}{ Number of isolates from tumours of } \\
\hline & $\begin{array}{l}\text { abdomen } \\
(14)^{*}\end{array}$ & $\begin{array}{l}\text { pelvis } \\
(5)\end{array}$ & $\begin{array}{l}\text { head and } \\
\text { neck } \\
(23)\end{array}$ & $\underset{(4)}{\operatorname{lung}}$ & $\begin{array}{l}\text { mediastinum } \\
\text { (4) }\end{array}$ & $\begin{array}{l}\text { lymphatics } \\
\text { (2) }\end{array}$ & $\begin{array}{l}\text { breast } \\
(3)\end{array}$ & $\begin{array}{l}\text { miscel- } \\
\text { laneous } \\
(8)\end{array}$ & $\begin{array}{l}\text { total } \\
(63)\end{array}$ \\
\hline $\begin{array}{l}\text { Aerobic and facultative } \\
\text { Streptococcus pyogenes }\end{array}$ & $\ldots$ & $\ldots$ & 2 & $\ldots$ & $\ldots$ & 1 & $\ldots$ & $\ldots$ & 3 \\
\hline Str. faecalis & 2 & $\cdots$ & $\ldots$ & $\cdots$ & $\ldots$ & $\cdots$ & $\ldots$ & $\cdots$ & 2 \\
\hline $\begin{array}{l}\alpha \text {-haemolytic strepto- } \\
\text { coccus }\end{array}$ & $\cdots$ & $\ldots$ & 2 & 1 & 1 & $\cdots$ & 1 & 2 & 7 \\
\hline Staphylococcus aureus & $\cdots$ & 1 & 3 & $\ldots$ & 2 & $\cdots$ & 1 & $\cdots$ & 7 \\
\hline S. epidermidis & 1 & $\ldots$ & 4 & $\ldots$ & $\cdots$ & $\cdots$ & $\cdots$ & $\cdots$ & 5 \\
\hline Escherichia coli & 4 & 2 & $\cdots$ & $\ldots$ & $\ldots$ & 1 & $\cdots$ & $\cdots$ & 7 \\
\hline Klebsiella pneumoniae & 1 & 1 & 1 & 2 & $\ldots$ & $\ldots$ & $\cdots$ & $\ldots$ & 5 \\
\hline Klebsiella oxytoca & 2 & $\ldots$ & $\ldots$ & $\ldots$ & $\ldots$ & $\ldots$ & $\ldots$ & $\cdots$ & 2 \\
\hline Acinetobacter sp. & ... & $\ldots$ & $\ldots$ & $\cdots$ & $\ldots$ & $\ldots$ & $\cdots$ & 1 & 1 \\
\hline Serratia marcescens & 1 & $\cdots$ & $\cdots$ & $\ldots$ & $\ldots$ & $\cdots$ & $\cdots$ & 1 & 2 \\
\hline $\begin{array}{l}\text { Pseudomonas aerugi- } \\
\text { nosa }\end{array}$ & 2 & $\cdots$ & 3 & $\cdots$ & $\cdots$ & $\cdots$ & $\cdots$ & $\cdots$ & 5 \\
\hline $\begin{array}{l}\text { Micro-aerophilic } \\
\text { streptococcus }\end{array}$ & $\cdots$ & $\ldots$ & $\cdots$ & 1 & $\cdots$ & $\cdots$ & $\cdots$ & $\cdots$ & 1 \\
\hline $\begin{array}{l}\text { Anaerobic } \\
\text { Peptostreptococcus sp. }\end{array}$ & 2 & 1 & 2 & 1 & & 1 & 1 & & 8 \\
\hline P. prevotii & $\ldots$ & $\ldots$ & 2 & $\ldots$ & $\ldots$ & $\ldots$ & 1 & $\ldots$ & 3 \\
\hline P. anaerobius & $\ldots$ & $\ldots$ & 1 & $\ldots$ & $\ldots$ & $\ldots$ & $\ldots$ & 1 & 2 \\
\hline P. magnus & $\ldots$ & $\ldots$ & 3 & 1 & $\ldots$ & $\ldots$ & 2 & 1 & 7 \\
\hline Veillonella sp. & $\ldots$ & 1 & $\ldots$ & $\ldots$ & $\ldots$ & $\ldots$ & $\ldots$ & $\ldots$ & 1 \\
\hline Bifidobacterium sp. & $\ldots$ & $\ldots$ & 1 & $\ldots$ & $\cdots$ & $\ldots$ & $\cdots$ & $\cdots$ & 1 \\
\hline Eubacterium sp. & $\cdots$ & $\ldots$ & $\cdots$ & $\cdots$ & $\cdots$ & $\cdots$ & $\cdots$ & 1 & 1 \\
\hline $\begin{array}{l}\text { Propionibacterium } \\
\text { acnes }\end{array}$ & 1 & 1 & 12 & $\ldots$ & 4 & $\ldots$ & $\ldots$ & 4 & 22 \\
\hline Clostridium sp. & 1 & $\ldots$ & $\ldots$ & $\cdots$ & $\cdots$ & $\cdots$ & $\cdots$ & $\ldots$ & 1 \\
\hline Fusobacterium sp. & $\ldots$ & 1 & $\cdots$ & $\ldots$ & $\cdots$ & $\cdots$ & $\ldots$ & $\ldots$ & 1 \\
\hline Bacteroides sp. & 2 & 1 & 1 & 1 & $\ldots$ & 1 & $\ldots$ & $\ldots$ & 6 \\
\hline B. fragilis & 5 & 1 & 2 & 1 & $\ldots$ & 1 & 1 & 2 & 13 \\
\hline B. ovatus & 1 & $\ldots$ & $\cdots$ & $\ldots$ & $\ldots$ & $\ldots$ & $\ldots$ & $\cdots$ & 1 \\
\hline B. thetaiotaomicron & 2 & 1 & $\ldots$ & $\ldots$ & $\cdots$ & $\ldots$ & $\ldots$ & $\ldots$ & 3 \\
\hline B. melaninogenicus & 2 & $\ldots$ & $\ldots$ & $\ldots$ & $\ldots$ & 1 & 2 & 3 & 8 \\
\hline B. oralis & 1 & ... & $\cdots$ & $\ldots$ & $\cdots$ & $\ldots$ & $\cdots$ & $\cdots$ & 1 \\
\hline B. oris-buccae & $\ldots$ & 1 & $\ldots$ & $\ldots$ & $\cdots$ & $\cdots$ & $\ldots$ & $\cdots$ & 1 \\
\hline B. loescheii & $\ldots$ & 1 & 1 & $\ldots$ & $\ldots$ & $\ldots$ & $\cdots$ & $\ldots$ & 2 \\
\hline B. ureolyticus & $\ldots$ & $\ldots$ & 1 & $\ldots$ & $\ldots$ & $\ldots$ & $\ldots$ & $\ldots$ & 1 \\
\hline
\end{tabular}

* Number of specimens.

infected abdominal tumours and the distribution of other anaerobes in different sites.

The frequent isolation of anaerobes from infected tumours is not surprising because, when tumours outgrow their blood supply and become necrotic, the resulting lowered oxygen tension may favour the growth of anaerobes (Brook, 1988). Anaerobic glycolysis is also significantly increased in tumour 
tissue, with a resulting accumulation of lactic acid in the tissue and its environment.

Spores of non-pathogenic Clostridium spp. can localise and germinate in neoplasms and produce extensive lysis of tumours without concomitant effect on normal tissue (Malmgren and Flanigan, 1955), and clostridial septicaemia originating from an infection within tumour lesions has been reported (Cabrera et al., 1965; Alpern and Dowell, 1969; Caya et al., 1986).

Synergy between the various bacteria that may be found in infected tumours has been demonstrated in patients as well as in animal models. Such synergy between anaerobic and aerobic bacteria causes mutual enhancement of growth (Brook, 1985), abscess formation and increased mortality in animals (Altemier, 1942; Hite et al., 1949; Brook et al., 1984).

\section{REFERENCES}

Alpern R J, Dowell V R 1969 Clostridum septicum infection and malignancy. Journal of the American Medical Association 209: 385-388.

Altemier W A 1942 The pathogenicity of the bacteria of appendicitis peritonitis; experimental study. Surgery 11: 374-384.

Ashby E C, Rees M, Dowding C H 1978 Prophylaxis against systemic infection after transrectal biopsy for suspected prostatic carcinoma. British Medical Journal ii : 1263-1264.

Bodey G P 1986 Infection in cancer patients. A continuing association. American Journal of Medicine 81 Suppl 1A: 1126.

Brook I 1985 Enhancement of growth of aerobic and facultative bacteria in mixed infections with Bacteroides species. Infection and Immunity 50: 929-931.

Brook I 1989 Pediatric anaerobic infection: diagnosis and management. C. V. Mosby Co., St Louis, MO.

Brook I, Hunter V, Walker R I 1984 Synergistic effect of Bacteroides, Clostridium, Fusobacterium, anaerobic cocci, and aerobic bacteria on mortality and induction of subcutaneous abscesses in mice. Journal of Infectious Diseases 149: 924-928.

Cabrera A, Tsukada Y, Pickren J W 1965 Clostridial gas gangrene and septicemia in malignant disease. Cancer 18: 800-806.

Caya J G et al. 1986 Clostridial septicemia complicating the course of leukemia. Cancer 57: 2045-2048.

Hite K E, Locke M, Hesseltine H C 1949 Synergism in
Polymicrobial aerobic and anaerobic infection in a necrotic tumour may represent a serious threat to the patient. Treatment, preferably by surgical removal or evacuation of pus should be complemented by antimicrobial therapy directed at the eradication of the anaerobic as well as the aerobic flora present.

I am grateful for the laboratory support of the Clinical Microbiology Laboratory staffs of Walter Reed Army Medical Center, Washington, DC, and the Navy Medical Center, Bethesda, MD, and the secretarial assistance of Pamela Botticher and Minerva G. Barreiro.

The opinion and assertions contained herein are the private ones of the writer and are not to be construed as official or reflecting the views of the Navy Department or the naval service at large.

experimental infections with nonsporulating anaerobic bacteria. Journal of Infectious Diseases 84: 1-9.

Klastersky J, Coppens L, Mombelli G 1979 Anaerobic infection in cancer patients: comparative evaluations of clindamycin and cefoxitin. Antimicrobial Agents and Chemotherapy 16: 366-371.

Klastersky J, Husson M, Weerts-Ruhl D, Daneau D 1977 Anaerobic wound infections in cancer patients: comparative trial of clindamycin, tinidazole and doxycycline. Antimicrobial Agents and Chemotherapy 12: 563-570.

Lagast H, Klastersky J 1982 Anaerobic infections in cancer patients-a retrospective analysis of clindamycin, tinidazole, doxycycline, cefoxitin and moxalactam. Infection 10: 144-148.

Lagast H, Meunier-Carpentier F, Klastersky J 1982 Moxalactam treatment of anaerobic infections in cancer patients. Antimicrobial Agents and Chemotherapy 22 : 604-610.

Lennette E H, Balows A, Hausler W J, Shadomy H J (eds) 1985 Manual of clinical microbiology, 4th edn. American Society for Microbiology, Washington, DC.

Malmgren R A, Flanigan C C 1955 Localization of the vegetative form of Clostridium tetani in mouse tumours following intravenous spore administration. Cancer Research 15: 473478.

Rotimi V O, Durosinmi-Etti F A 1984 The bacteriology of infected malignant ulcers. Journal of Clinical Pathology 37: 592-595.

Sinkovics J G, Smith J P 1970 Septicemia with bacteroides in patients with malignant disease. Cancer 25: 663-671.

Sutter V L, Citron D M, Edelstein M A C, Finegold S M 1985 Wadsworth anaerobic bacteriology manual, 4th edn. Star Publishing Co., Belmont, CA. 